\title{
Synthesis and cytotoxicity evaluation of thiosemicarbazones and their thiazole derivatives
}

\author{
Saulo Feheiberg Pinto Braga ${ }^{1}$, Nayara Cristina Fonseca ${ }^{1}$, Jonas Pereira Ramos ${ }^{2}$, Elaine Maria de \\ Souza-Fagundes ${ }^{2}$, Renata Barbosa de Oliveira ${ }^{1, *}$
}

${ }^{I}$ Departament of Pharmaceutical Products, Faculty of Pharmacy, Federal University of Minas Gerais, Belo Horizonte, MG, Brasil, ${ }^{2}$ Departament of Physiology and Biophysics, Institute of Biological Sciences, Federal University of Minas Gerais, Belo Horizonte, $M G$, Brasil

\begin{abstract}
The aims of this study were to synthesize a series of thiosemicarbazones and their thiazole derivatives, to investigate their cytotoxic activity against three human cancers and normal (Vero cells) cell lines, and to evaluate the pro-apoptotic potential of the most active compounds. Materials and Methods: The thiosemicarbazones were obtained by reacting an aromatic aldehyde with thiosemicarbazide (yield $71-96 \%$ ), which were subjected to a cyclization with $\alpha$-bromoacetophenone to yield the required thiazole heterocycles (yield 63-100\%). All the synthesized compounds were screened at $50 \mu \mathrm{M}$ concentration against three cell lines representing HL60 (promyelocytic leukemia), Jurkat (acute lymphoblastic leukemia), and MCF-7 (breast cancer). The pro-apoptotic effect was measured by flow cytometry as the percentage of cells with hypodiploid DNA. Results: Three thiazole compounds showed activity against at least one tumor cell line $\left(\mathrm{IC}_{50}=43-76 \mu \mathrm{M}\right)$ and low cytotoxicity against Vero cells $\left(\mathrm{IC}_{50}>100 \mu \mathrm{M}\right)$. The most active compound of this series induced $91 \%$ and $51 \%$ DNA fragmentation in HL60 and MCF-7 cell lines, respectively, suggesting that this compound triggered apoptosis in these cells. Conclusion: Among the synthesized compounds, one in particular was found to exert antiproliferative and pro-apoptotic activity on tumor cells and can be considered promising as a lead molecule for the design of new analogues with improved activity.
\end{abstract}

Uniterms: Thiosemicarbazones/synthesis. Thiosemicarbazones/cytotoxic activity. Thiazoles/derivatives/ synthesis. Thiazoles/derivatives/cytotoxic activity.

O estudo teve como objetivo a síntese de uma série de tiossemicarbazonas e seus derivados tiazólicos e a avaliação da atividade citotóxica contra três linhagens de células tumorais humanas e células normais (Vero), a fim de se avaliar o potencial pró-apoptótico dos compostos mais ativos. As tiossemicarbazonas foram obtidas por reação entre um aldeído aromático e tiossemicarbazida (rend. 71-96\%), as quais foram submetidas à ciclização com $\alpha$-bromoacetofenona, fornecendo os heterociclos tiazólicos desejados (rend. 63-100\%). Todos os compostos sintetizados foram testados na concentração de $50 \mu \mathrm{M}$ contra três linhagens de células tumorais: HL60 (leucemia promielocítica), Jurkat (leucemia linfoblástica aguda) e MCF-7 (câncer de mama). O efeito pró-apoptótico foi avaliado por citometria de fluxo como porcentagem de células com DNA hipodiplóide. Três compostos tiazólicos foram ativos contra, pelo menos, uma linhagem tumoral $\left(\mathrm{CI}_{50}=43-76 \mu \mathrm{M}\right)$, com baixa citotoxicidade contra células Vero $\left(\mathrm{CI}_{50}>100 \mu \mathrm{M}\right)$. O composto mais ativo dessa série induziu fragmentação do DNA de 91\% e 51\% nas linhagens HL60 e MCF-7, respectivamente, sugerindo que este composto ativou a apoptose nessas células. Dentre os compostos sintetizados, um em particular apresentou atividade antiproliferativa e pró-apoptótica em células tumorais e pode ser considerado composto protótipo promissor na busca por novos análogos com atividade melhorada.

Unitermos: Tiossemicarbazonas/síntese. Tiossemicarbazonas/atividade citotóxica. Tiazol/derivados/ síntese. Tiazol/derivados/atividade citotóxica.

\footnotetext{
*Correspondence: R. B. Oliveira. Departamento de Produtos Farmacêuticos. Faculdade de Farmácia. Universidade Federal de Minas Gerais. Av. Antônio Carlos 6627 - 31270-901 - Belo Horizonte - MG, Brasil. E-mail: renatabo@farmacia.ufmg.br
} 


\section{INTRODUCTION}

Thiosemicarbazones and their thiazole heterocyclic derivatives are of great importance in pharmacology due to their broad range of biological activities, such as anticonvulsant, antimicrobial, and antiparasitic activities (Gaikwad, Patil, Bobade, 2013; Souza et al., 2013; Bharti et al., 2010; Siddiqui et al., 2009; Oliveira et al., 2008a; Souza, 2005; Dimmock et al., 1991).

The synthesis of thiazole compounds from thiosemicarbazones is of particular interest in medicinal chemistry due to their ease of synthesis, low cost, good yields, and the possibility of obtaining a wide diversity of derivatives, allowing the modulation of pharmacokinetics and optimization of biological activity. In addition, this class of heterocyclic compounds has demonstrated great potential as anticancer agents with a broad spectrum of action against different types of cancer cell lines (AbdelMaksoud et al., 2016; Turan-Zitouni et al., 2016; Morigi et al., 2015; Zhao et al., 2015).

In this context, and following the work developed by our research group in the development of new compounds with antitumor activity (Lages et al., 2013; Soares et al., 2010), the present study aimed to synthesize thiosemicarbazones and their thiazole derivatives (Figure 1) and to evaluate their antiproliferative activity against three human tumor cell lines: HL60 (promyelocytic leukemia), Jurkat (acute lymphoblastic leukemia), and MCF-7 (breast cancer). The cytotoxic activity against Vero cell lines (normal monkey kidney cells) was also aimed to investigate the selectivity of the compounds to nontumor cells, which have been used as a preliminary model to assess the selectivity of new bioactive compounds (Lavrado et al., 2010; Küster et al., 2012).

Apoptosis or programmed cell death is an important parameter in drug-induced toxicity (Weber et al., 2004). Deregulation of apoptosis-regulating genes can lead to diseases such as cancer and has been related to pathogenesis and cancer progression (Fischer, SchulzeOsthoff, 2005). Drugs that restore the normal apoptotic pathways have the potential for effectively treating cancers that depend on aberrations of the apoptotic pathway to stay alive (Fesik, 2005). Therefore, the search for compounds capable of inducing apoptosis in tumor cells is of great interest in the development of novel drugs for cancer treatment. In this context, we also evaluated the apoptotic potential of the active compounds measuring the increase of diploid DNA content of susceptible cells by flow cytometry, as a preliminary study to gain insights into their action mechanism comparing with etoposide, a pro-apoptotic drug used in the clinic.

\section{MATERIAL AND METHODS}

\section{General procedures}

Melting points were determined on a Microquímica MQAPF 301 apparatus and are uncorrected. FT-IR spectra were recorded using a Perkin Elmer Spectrum One infrared spectrometer and absorptions are reported as wave numbers $\left(\mathrm{cm}^{-1}\right)$. All NMR spectra were recorded on a Bruker Avance DPX 200 spectrometer $(200 \mathrm{MHz})$. Chemical shifts are given in $\delta(\mathrm{ppm})$ scale and $J$ values are given in $\mathrm{Hz}$. All reagents of analytical grade were obtained from commercial suppliers and used without previous purification. Reactions were monitored by TLC using silica gel coated plates and different solvents solutions as the mobile phase. The synthesis of the compounds 1a and 1c (Rajak et al., 2011), 1b (Tenório, Carvalho, Pessanha, 2005), 1d (Grammaticakis, Sorbonne, 1959), 1e (Behnisch, Mietzsch, Schmidt, 1955), 1 (Oliveira et al., 2008b), 2a and 2c (Shih, Su, Wu, 2007), 2b (Maccioni et al., 2003) and 2e (Bilinski, Tyburczyk, Urban, 1961) was previously reported in the literature.

\section{General procedure: synthesis of thiazole heterocycles (Dimmock et al., 1991)}

To a solution of 1 equiv. of thiosemicarbazones (1a-1f) in isopropyl alcohol was added 1 equiv. of 2-bromoacetophenone or 2-bromo-4' methoxyacetophenone, and the resulting mixture was kept under reflux and magnetic stirring (approximately 90 minutes or indicated time). After cooling to room temperature, part of the solvent was removed under
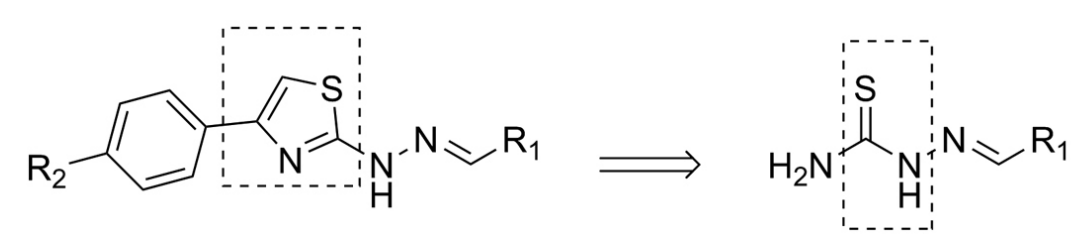

Thiazole heterocycles

\section{Thiosemicarbazones}

\footnotetext{
FIGURE 1 - General structure of synthesized thiosemicarbazones and hetetocycles.
} 
reduced pressure and the formed precipitate was filtered, washed with saturated solution of $\mathrm{NaHCO}_{3}$ followed by cold distilled water.

\section{4-Phenyl-2-(2-(quinolin-4-ylmethylene)hydrazinyl) thiazole (2d).}

The reaction was carried out following the general procedure described above affording $0.141 \mathrm{~g}$ of a brownish solid (65\% yield). Mp $112.0-114.5^{\circ} \mathrm{C}$. IR, $\left(\bar{v} / \mathrm{cm}^{-1}\right)$ : $3452(\mathrm{NH}), 1659(\mathrm{C}=\mathrm{N}), 1619,1594,1551,1452(\mathrm{C}=\mathrm{C}$ aromatic). ${ }^{1} \mathrm{H}$ NMR $\left(200 \mathrm{MHz}, \mathrm{DMSO}-\mathrm{d}_{6}\right), \delta / \mathrm{ppm}: 12.68$ (1 H, s, N $\underline{\mathrm{H}}) ; 8.94$ (1 H, d, quinoline); 8.93-8.70 (2 H, m, quinoline and $\mathrm{C} \underline{\mathrm{H}}=\mathrm{N}) ; 8.07$ (1 H, d, H-8 quinoline); 7.907.68 (5 H, m, quinoline and ArH); 7.46-7.27 (4 H, m, ArH and $\mathrm{H}$-thiazole). ${ }^{13} \mathrm{C}$ NMR (50 MHz, DMSO-d $\left.\mathrm{d}_{6}\right), \delta / \mathrm{ppm}$ : $167.7(\mathrm{SC}=\mathrm{N}) ; 150.7 ; 150.2 ; 148.3(\mathrm{C}-4$ thiazole, $\mathrm{C}-2$, C-9 quinoline); $138.0(\underline{\mathrm{CH}}=\mathrm{N}) ; 137.4(\mathrm{C}-4$ quinoline $)$; 134.5 (C-Ph); 129.7, 129.6, 128.6 (C-Ph), 127.7, 127.4, 125.6 (C-Ph), 124.2 (C-5, C-6, C-7, C-8 quinoline and $\mathrm{C}-\mathrm{Ph}) ; 124.3$ (C-10 quinoline); 119.0 (C-3 quinoline); 104.5 (ㅁH-thiazole).

\section{2-(2-((5-(4-Nitrophenyl)furan-2-yl)methylene) \\ hydrazinyl)-4-phenylthiazole (2f).}

The reaction was carried out following the general procedure described above affording $0.066 \mathrm{~g}$ of an orange solid ( $92 \%$ yield). $\mathrm{Mp} 208.3{ }^{\circ} \mathrm{C}$ with decomposition. IR, $\left(\overline{\mathrm{v}} / \mathrm{cm}^{-1}\right): 1597(\mathrm{C}=\mathrm{N}), 1580,1562,1483(\mathrm{C}=\mathrm{C}$ aromatic $)$, 1508, $1343\left(\mathrm{NO}_{2}\right) .{ }^{1} \mathrm{H}$ NMR $\left(200 \mathrm{MHz}, \mathrm{DMSO}-\mathrm{d}_{6}\right), \delta / \mathrm{ppm}$ : $12.33(1 \mathrm{H}, \mathrm{s}, \mathrm{N} \underline{\mathrm{H}}) ; 8.29\left(2 \mathrm{H}\right.$, broad s., $\left.\mathrm{ArNO}_{2}\right) ; 7.98(3 \mathrm{H}$, broad s., $\left.\mathrm{C} \underline{\mathrm{H}}=\mathrm{N}+\mathrm{ArNO}_{2}\right) ; 7.85$ (2 H, br. s., ArH); 7.42$7.37(5 \mathrm{H}, \mathrm{m}, 2 \mathrm{x}$ ArH, H-thiazole and $\mathrm{H}-5$ furan); 7.00 (1 $\mathrm{H}, \mathrm{s}, \mathrm{H}-2$ furan). ${ }^{13} \mathrm{C}$ NMR (50 MHz, DMSO-d $\mathrm{d}_{6}$ ), $\delta / \mathrm{ppm}$ : 167.6 $(\mathrm{SC}=\mathrm{N}) ; 151.6,151.1,150.4(\mathrm{C}-4$ thiazole, $\mathrm{C}-2$ and C-5 furan); $146.1\left(\mathrm{C}-\mathrm{ArNO}_{2}\right) ; 135.3,134.5\left(\mathrm{C}-\mathrm{ArNO}_{2}\right.$ and $\mathrm{C}-\mathrm{Ph}) ; 130.7(\underline{\mathrm{CHC}}=\mathrm{N}) ; 128.6(\mathrm{C}-\mathrm{Ph}), 127.6(\mathrm{C}-\mathrm{Ph}) ; 125.9$ (C-Ph); 124.5, $124.2\left(\mathrm{C}-\mathrm{ArNO}_{2}\right) ; 114.2$ (C-4 furan); 112.6 (C-3 furan); 103.9 ( $\underline{\mathrm{C}} \mathrm{H}-$ thiazole).

\section{4-(4-Methoxyphenyl)-2-(2-(3-nitrobenzylidene) hydrazinyl)thiazole (2g).}

The reaction was carried out following the general procedure described above affording $0.168 \mathrm{~g}$ of a yellow solid (quantitative yield). Mp 190.0-193. $3^{\circ} \mathrm{C}$. IR, ( $\bar{v} /$ $\left.\mathrm{cm}^{-1}\right)$ : $3314(\mathrm{NH}), 1587(\mathrm{C}=\mathrm{N}), 1527,1346\left(\mathrm{NO}_{2}\right), 1511$, $1463\left(\mathrm{C}=\mathrm{C}\right.$ aromatic). ${ }^{1} \mathrm{H}$ NMR $\left(200 \mathrm{MHz}, \mathrm{DMSO}_{-} \mathrm{d}_{6}\right)$, $\delta /$ ppm: $8.45\left(1 \mathrm{H}, \mathrm{s}, \mathrm{ArNO}_{2}\right) ; 8.20-8.16\left(2 \mathrm{H}, \mathrm{m}, \mathrm{ArNO}_{2}\right.$ and $\underline{\mathrm{HC}}=\mathrm{N}) ; 8.07\left(1 \mathrm{H}, \mathrm{d}, \mathrm{ArNO}_{2}\right) ; 7.79-7.67(3 \mathrm{H}, \mathrm{m}$, $\mathrm{ArNO}_{2}$ and $\left.\mathrm{ArOCH}_{3}\right) ; 7.19(1 \mathrm{H}, \mathrm{s}, \mathrm{H}$-thiazole $) ; 6.97$ (2 $\left.\mathrm{H}, \mathrm{d}, \mathrm{ArOCH}_{3}\right) ; 3.77\left(3 \mathrm{H}, \mathrm{s}, \mathrm{OC}_{3}\right) .{ }^{13} \mathrm{C} \mathrm{NMR}(50 \mathrm{MHz}$, DMSO-d $\left.{ }_{6}\right), \delta / p p m: 167.9(\mathrm{~S} \underline{\mathrm{C}}=\mathrm{N}) ; 159.0\left(\mathrm{C}-\mathrm{ArOCH}_{3}\right)$;
148.3 (C-4 thiazole); $151.5\left(\mathrm{C}-\mathrm{ArNO}_{2}\right) ; 139.4(\underline{\mathrm{CH}}=\mathrm{N})$; $136.2\left(\mathrm{C}-\mathrm{ArNO}_{2}\right) ; 132.4\left(\mathrm{C}-\mathrm{ArNO}_{2}\right) ; 130.4\left(\mathrm{C}-\mathrm{ArNO}_{2}\right)$; $127.0\left(\mathrm{C}-\mathrm{ArOCH}_{3}\right) ; 126.9\left(\mathrm{C}-\mathrm{ArOCH}_{3}\right) ; 123.4\left(\mathrm{C}-\mathrm{ArNO}_{2}\right)$; $120.3\left(\mathrm{C}-\mathrm{ArNO}_{2}\right) ; 114.0\left(\mathrm{C}-\mathrm{ArOCH}_{3}\right) ; 102.2(\underline{\mathrm{CH}}-$ thiazole); $55.2\left(\mathrm{OCH}_{3}\right)$.

\section{4-(4-Methoxyphenyl)-2-(2-(quinolin-4-ylmethylene) hydrazinyl)thiazole (2h).}

The reaction was carried out following the general procedure described above affording 0.146 $\mathrm{g}$ of a brownish solid (94\% yield). Mp $97.7^{\circ} \mathrm{C}$ with decomposition. IR, $\left(\overline{\mathrm{v}} / \mathrm{cm}^{-1}\right)$ : $3420(\mathrm{NH}), 1580(\mathrm{C}=\mathrm{N})$, 1552, 1505, 1488 ( $\mathrm{C}=\mathrm{C}$ aromatic). ${ }^{1} \mathrm{H}$ NMR $(200 \mathrm{MHz}$, DMSO-d $\left.{ }_{6}\right), \delta / p p m: 12.67(1 \mathrm{H}, \mathrm{s}, \mathrm{NH}) ; 8.94(1 \mathrm{H}, \mathrm{d}$, $\mathrm{H}$-quinoline); 8.69 e $8.64(2 \mathrm{H}, \mathrm{m}, \mathrm{H}$-quinoline and $\mathrm{C} \underline{\mathrm{H}}=\mathrm{N}) ; 8.08(1 \mathrm{H}, \mathrm{d}, \mathrm{H}$-quinoline $) ; 7.82-7.68(5 \mathrm{H}, \mathrm{m}$, $\mathrm{H}$-quinoline and $\left.\mathrm{ArOCH}_{3}\right) ; 7,24(1 \mathrm{H}, \mathrm{s}, \mathrm{H}$-thiazole $)$; $6.97\left(2 \mathrm{H}, \mathrm{d}, \mathrm{ArOCH}_{3}\right) ; 3.78\left(3 \mathrm{H}, \mathrm{s}, \mathrm{OC}_{3}\right) .{ }^{13} \mathrm{C} \mathrm{NMR}$ $\left(50 \mathrm{MHz}, \mathrm{DMSO}-d_{6}\right), \delta / \mathrm{ppm}$ : $168.0(\mathrm{SC}=\mathrm{N}) ; 159.3$ $\left(\mathrm{C}-\mathrm{ArOCH}_{3}\right) ; 150.9,150.4,148.5(\mathrm{C}-4$ thiazole, $2 \mathrm{x}$ C-quinoline); 138.2 (C-quinoline); $137.9(\underline{\mathrm{CH}}=\mathrm{N}) ; 130.1$, 130.0 (2 x C-quinoline); 127.8 (C-quinoline); 127.7 $\left(\mathrm{C}-\mathrm{ArOCH}_{3}\right) ; 127.3$ (C-quinoline); $124.7\left(\mathrm{C}-\mathrm{ArOCH}_{3}\right)$; 126.6 (C-quinoline); 119.3 (C-quinoline); 114.4 $\left(\mathrm{C}-\mathrm{ArOCH}_{3}\right) ; 102.7$ ( $\underline{\mathrm{CH}}$-thiazole); $55.5\left(\mathrm{OCH}_{3}\right)$.

\section{4-(4-Methoxyphenyl)-2-(2-((5-(4-nitrophenyl)furan-2- yl)methylene)hydrazinyl)thiazole (2i).}

The reaction was carried out following the general procedure described above affording $0.080 \mathrm{~g}$ of a dark red solid (quantitative yield). $\mathrm{Mp} 202.9^{\circ} \mathrm{C}$ with decomposition. IR, $\left(\overline{\mathrm{v}} / \mathrm{cm}^{-1}\right): 3372(\mathrm{NH}), 1618(\mathrm{C}=\mathrm{N})$, 1608, 1608, $1487(\mathrm{C}=\mathrm{C}$ aromatic $), 1509,1331\left(\mathrm{NO}_{2}\right) .{ }^{1} \mathrm{H}$ NMR (200 MHz, DMSO-d $)$, $\delta /$ ppm: $8.26(2 \mathrm{H}$, broad s., $\left.\mathrm{ArNO}_{2}\right)$; 7.99-7.96 (3 H, m, $\left.\mathrm{C} \underline{\mathrm{H}}=\mathrm{N}+\mathrm{ArNO}_{2}\right) ; 7.75(2 \mathrm{H}$, broad s., $\left.\mathrm{ArOCH}_{3}\right) ; 7.42(1 \mathrm{H}, \mathrm{s}, \mathrm{H}$-thiazole $) ; 7.19(1 \mathrm{H}, \mathrm{s}$, $\mathrm{H}-4$ furan); 6.99 (4 H, broad s., $\mathrm{NH}, \mathrm{H}-3$ furan, $\mathrm{ArOCH}_{3}$ ); $3.78\left(3 \mathrm{H}, \mathrm{s}, \mathrm{OC}_{3}\right) \cdot{ }^{13} \mathrm{C} \mathrm{NMR}\left(50 \mathrm{MHz}, \mathrm{DMSO}-\mathrm{d}_{6}\right), \delta /$ ppm: $167.7(\mathrm{SC}=\mathrm{N}) ; 159.0\left(\mathrm{C}-\mathrm{ArOCH}_{3}\right) ; 151.8,151.0$, 149.2 (C-4 thiazole, C-2 and C-5 furan); $146.1\left(\mathrm{C}-\mathrm{ArNO}_{2}\right)$; $135.2\left(\mathrm{C}-\mathrm{ArNO}_{2}\right) ; 131.5(\underline{\mathrm{CHC}}=\mathrm{N}) ; 126.9\left(\mathrm{C}-\mathrm{ArOCH}_{3}\right)$; $126.7\left(\mathrm{C}-\mathrm{ArOCH}_{3}\right) ; 124.5,124.3\left(\mathrm{C}-\mathrm{ArNO}_{2}\right) ; 114.7(\mathrm{C}-4$ furan); $114.0\left(\mathrm{C}-\mathrm{ArOCH}_{3}\right) ; 112.8$ (C-3 furan); 102.1 ( $\underline{\mathrm{CH}}$ thiazole); $55.2\left(\mathrm{OCH}_{3}\right)$.

\section{Biological assays}

\section{Cell lines}

Jurkat (human T cells leukemia), HL-60 (human promyelocytic leukemia) and MCF-7 (breast carcinoma) cell lines were generously donated by Dr. Gustavo P. 
Amarante-Mendes of Universidade de São Paulo-USP and Professor Alfredo Goes (Universidade Federal de Minas Gerais). Vero cells (derived from the kidney of an African green monkey) were donated by Erna Kroon (Universidade Federal de Minas Gerais).

Leukemic cells were kept in a RPMI 1640 medium (Sigma Aldrich, USA) supplemented with $1 \%$ antibiotic solution $(100 \mathrm{U} / \mathrm{mL}$ penicillin and $100 \mu \mathrm{g} / \mathrm{mL}$ streptomycin - GIBCO BRL, Grand Island, NY), buffered with $2 \mathrm{mM}$ of L-glutamina (GIBCO UK, Grand Island, NY) 10\% of fetal bovine serum (GIBCO BRL, Grand Island, NY), being incubated under a $5 \% \mathrm{CO}_{2}$ atmosphere at $37^{\circ} \mathrm{C}$. MCF-7 cells were kept in D-MEM (Sigma Aldrich, USA), supplemented as described for leukemic cells but $5 \%$ of fetal bovine serum. All cultures were maintained at $37^{\circ} \mathrm{C}$ in a humidified incubator with $5 \% \mathrm{CO}_{2}$ and $95 \%$ air. The media were changed twice weekly and they were regularly examined.

\section{Cytotoxicity assays}

The screening assays to evaluate the cytotoxic effects of the thiosemicarbazones and their thiazole derivatives were performed in 96 well plate using HL60 and Jurkat cells at 50,000 and 100,000 cells/well, respectively. MCF-7 and Vero cells were seeded at 10,000 cells/well. The plates were pre-incubated for $24 \mathrm{~h}$ at $37^{\circ} \mathrm{C}$ to allow adaptation of cells prior to the addition of the compounds at $50 \mu \mathrm{M}$. Treated and untreated cells (DMSO $0.5 \%$ ) were incubated for 48 hours and compounds that inhibited the cell viability greater than $50 \%$ had the $\mathrm{IC}_{50}$ values obtained graphically from concentration-effect curves using Prism 5.0 (GraphPad Software Inc.). Etoposide was used as positive control under the same experimental conditions. All substances were evaluated in two independent experiments, in triplicate. Cell viability was estimated by MTT assay.

\section{In vitro cell viability assay - MTT assay}

Viability assay was measured by MTT method (Mosmann, 1983). In brief, after 4 hours of the end of incubation of cells with different compounds, $20 \mu \mathrm{L}$ of MTT solution ( $5 \mathrm{mg} / \mathrm{mL}$ in phosphate-buffered saline) were added to each well, the supernatant was removed and $200 \mu \mathrm{L}$ of $0.04 \mathrm{M} \mathrm{HCl}$ in isopropyl alcohol were added to solve the formazan crystal. Absorbance of the samples (treated and untreated) was measured at in a spectrophotometer at $570 \mathrm{~nm}$. Data were expressed as perceptual of cell viability comparing with DMSO (0.5\%). Values of absorbance of medium plus drugs, without cells were used to escape from false positive or false negative (Ulukaya, Colakogullari, Wood, 2004).
Determination of hypodiploid DNA content by using a hypotonic fluorochrome solution (HFS)

The proapoptotic potential of the most actives compounds was evaluated by quantifying of hypodiploid DNA content, as described by Nicoletti and coworkers (1991). The cells were treated with compounds $(50 \mu \mathrm{M})$ and incubated for 24 hours. A total of $2.0 \times 10^{5}$ cells were resuspended in $0.3 \mathrm{ml}$ of hypotonic fluorochrome solution $(50 \mu \mathrm{g} / \mathrm{mL}$ propidium iodide and $0.1 \%$ Triton $\mathrm{X}-100$ in $0.1 \%$ sodium citrate). After $2-4 \mathrm{~h}$ at $4{ }^{\circ} \mathrm{C}$ in the dark, the fluorescence of individual nuclei was measured using a FACS flow cytometer (Becton-Dickinson, Mountain View, CA).

\section{RESULTS AND DISCUSSION}

The thiosemicarbazones (1a-f) and their cyclic derivatives (2a-i) were synthesized as shown in Figure 2. Initially, the thiosemicarbazones were obtained using a classic methodology, by reacting an aromatic aldehyde with thiosemicarbazide. Then, the thiosemicarbazones were subjected to a cyclization reaction in the presence of $\alpha$-bromoacetophenone. Non-substituted $\alpha$-bromoacetophenone $\left(\mathrm{R}_{2}=\mathrm{H}\right)$ or para substituted by a methoxyl group $\left(\mathrm{R}_{2}=\mathrm{OCH}_{3}\right)$ were used for comparison purpose. The presence of a methoxyl group, besides improving compound solubility, could contribute as a possible hydrogen bond acceptor with the molecular target.

All compounds were tested at $50 \mu \mathrm{M}$ against three human cancer cell lines: HL60 (promyelocytic leukemia), Jurkat (acute lymphoblastic leukemia), and MCF-7 (breast cancer) (Table I). The drug etoposide was utilized at $10 \mu \mathrm{M}$ as positive control.

Three compounds were able to inhibit more than $50 \%$ of the growth of at least one of the cancer cell lines and then their $\mathrm{IC}_{50}$ values were determined. In addition, cytotoxicity of the active compounds was evaluated against African green monkey kidney epithelial cells (Vero cells), a model used to investigate possible toxicity against non-tumor cell lines (Küster et al., 2012) (Table II).

Results from the initial screening allowed us to select three compounds (2d, 2f, and $\mathbf{2 h}$ ) able to inhibit more than $50 \%$ of viability of breast carcinoma cells (MCF-7) $\left(\mathrm{IC}_{50}\right.$ values 54,43 , and $76 \mu \mathrm{M}$, respectively). Among the tested compounds, only the thiazole $\mathbf{2 h}$ exhibited activity against promyelocytic leukemia cells (HL-60) with an $\mathrm{IC}_{50}$ value of $43 \mu \mathrm{M}$. None of the compounds tested showed significant cytotoxic activity against Jurkat cells. The concentration of the three compounds that inhibited Vero 


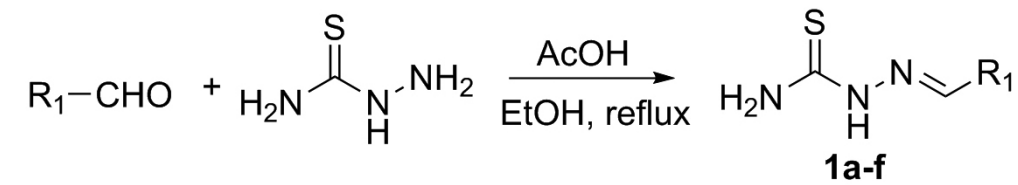

2a: $R_{1}=P h ; R_{2}=H$

2b: $\mathrm{R}_{1}=3-\mathrm{NO}_{2} \mathrm{C}_{6} \mathrm{H}_{4} ; \mathrm{R}_{2}=\mathrm{H}$

$71-96 \%$

2c: $\mathrm{R}_{1}=4-\mathrm{CH}_{3} \mathrm{C}_{6} \mathrm{H}_{4} ; \mathrm{R}_{2}=\mathrm{H}$

2d: $R_{1}=4$-quinoline; $\mathrm{R}_{2}=\mathrm{H}$

2e: $R_{1}=4$-pyridine; $R_{2}=H$

2f: $R_{1}=2$-(5-(4-nitrophenyl))furan; $\mathrm{R}_{2}=\mathrm{H}$

2g: $\mathrm{R}_{1}=3-\mathrm{NO}_{2} \mathrm{C}_{6} \mathrm{H}_{4} ; \mathrm{R}_{2}=\mathrm{OCH}_{3}$

2h: $\mathrm{R}_{1}=4$-quinoline; $\mathrm{R}_{2}=\mathrm{OCH}_{3}$

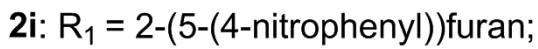
$\mathrm{R}_{2}=\mathrm{OCH}_{3}$<smiles>[R2]c1ccc(C(=O)CBr)cc1</smiles>

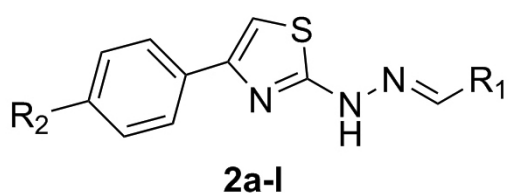

$63-100 \%$

FIGURE 2 - Route of synthesis of the thiosemizarbazones and their corresponding thiazole heterocycles.

cell proliferation by $50 \%\left(\mathrm{IC}_{50}\right)$ was greater than $100 \mu \mathrm{M}$, indicating low toxicity.

Accordingly with the results obtained, we were able to conclude that the presence of a thiazole ring is essential for activity against MCF-7 cells, since corresponding thiosemicarbazones $\mathbf{1 d}$ and $\mathbf{1 f}$, at the same concentration, were less active. Furthermore, in some cases, the presence of a second heterocyclic ring, quinoline ( $\mathbf{2} \mathbf{d}$ and $\mathbf{2 h}$ ) or furan (2f), favored the cytotoxic activity. However, for the pyridine derivative $\mathbf{2} \mathbf{e}$ and furan derivative $\mathbf{2} \mathbf{i}$, the presence of an additional heterocyclic ring did not result in a significant improvement in the activity. With respect to antiproliferative activity against HL-60 cells, comparison between $\mathbf{2 d}$ and $\mathbf{2} \mathbf{h}$ indicates the importance of the methoxyl group.

The effect of anticancer drugs on tumor cell lines such as HL60 and MCF-7 has been associated with apoptosis induction (Robinson, Shewach, 2001). In order to identify the pro-apoptotic potential of the more promising compounds ( $\mathbf{2 d}, \mathbf{2} \mathbf{f}$ and $\mathbf{2 h}$ ), the hypodiploid DNA content, which permits the evaluation of DNA fragmentation of cells undergoing apoptosis, was determined. In this assay, propidium iodide intercalates into the base pairs of doublestranded DNA, allowing the quantification of subdiploid DNA content and of the cells in different phases of the cell cycle (vide experimental section for details). The results summarized in Table II show that compound $\mathbf{2 h}$ induced a significant increase $(90 \%)$ of subdiploid DNA content in HL-60 cells, similar to etoposide. Regarding the MCF7 cells, the three compounds tested induced an increase of approximately $50 \%$ in the hypodiploid DNA. These data suggest that the cytotoxic effect of these compounds is related to the activation of the apoptosis pathways. It is noteworthy that etoposide exhibits low activity $\left(\mathrm{IC}_{50}>100 \mu \mathrm{M}\right)$ against MCF-7 cells.

The susceptibility of HL60 and MCF-7 to the thiazole compounds $\mathbf{2 d}, \mathbf{2} \mathbf{f}$, and $\mathbf{2 h}$ can be correlated with p53 status, a tumor suppressor that is responsible for triggering distinct responses to cellular stress and for mediating several of the antiproliferative processes, including apoptosis induction in response to DNA damage, among others (Fridman, Lowe, 2003). Cancer cells that express only mutated $\mathrm{p} 53$ protein have shown differential sensitivity to therapeutic modalities such as chemotherapeutic drugs or ionizing radiation, mediated by its inability to recognize DNA damage and promote damage repair or apoptosis (Robinson, Shewach, 2001; Ju et al., 1998). In the current investigation, the two lineages more susceptible to the new thiazole compounds possess different status of the $\mathrm{p} 53$ protein. HL60 (promyelocytic leukemia) lacks p53 (p53-null), which is very sensitive to various apopotic stimuli (Shimizu, Pommier, 1996), and MCF-7 (human breast carcinoma), a wild-type p53 (Robinson, Shewach, 2001). The two strains showed differential behavior towards the treatments with the three promising compounds. Whereas HL60 was sensitive only to $\mathbf{2 h}, \mathrm{MCF}-7$ cells demonstrated more sensibility to the three compounds. Compound $\mathbf{2 h}$ induced DNA fragmentation in both lineages (p53-null and wild-type). Since the HL-60 cell line does not express p53, it may be concluded that apoptosis induced by $\mathbf{2 h}$ is not dependent on this pathway. Therefore, this thiosemicarbazone can trigger different mechanisms of cell death independent of p53, which needs to be further investigated. 
TABLE I - Cytotoxicity activity assay results of synthesized compounds against tumor cells

$$
\underset{1 a-f}{\mathrm{H}_{2} \mathrm{~N}^{-}} \stackrel{\mathrm{N}_{2}^{-}}{\mathrm{N}} \approx R_{1}
$$

\begin{tabular}{|c|c|c|c|c|c|}
\hline \multirow{2}{*}{ Compounds } & \multirow{2}{*}{$\mathbf{R}_{1}$} & \multirow{2}{*}{$\mathbf{R}_{\mathbf{2}}$} & \multicolumn{3}{|c|}{$\%$ inhibition of cell proliferation } \\
\hline & & & HL60 & Jurkat & MCF-7 \\
\hline$\overline{1 a}$ & $\mathrm{Ph}$ & - & $5.9 \pm 3.7$ & 0 & $8.5 \pm 3.5$ \\
\hline $1 b$ & & - & $23.3 \pm 6.0$ & $16.0 \pm 4.3$ & $2.6 \pm 3.5$ \\
\hline $1 \mathrm{c}$ & & - & $11.6 \pm 5.0$ & $6.2 \pm 2.1$ & $24.7 \pm 0.4$ \\
\hline 1d & & - & 0 & $38.2 \pm 10.5$ & $28.9 \pm 6.1$ \\
\hline $1 \mathrm{e}$ & & - & 0 & 0 & $10.9 \pm 4.5$ \\
\hline 1f & & - & $7.5 \pm 1.0$ & $37.6 \pm 6.5$ & $11.0 \pm 7.0$ \\
\hline $2 a$ & $\mathrm{Ph}$ & $\mathrm{H}$ & $9.2 \pm 0.3$ & $2.9 \pm 2.3$ & $19.3 \pm 5.4$ \\
\hline $2 b$ & & $\mathrm{H}$ & 0 & $15.4 \pm 7.9$ & $33.5 \pm 3.6$ \\
\hline $2 c$ & & $\mathrm{H}$ & $16.9 \pm 4.2$ & 0 & $4.3 \pm 0.6$ \\
\hline $2 d$ & & $\mathrm{H}$ & $45.7 \pm 1.6$ & $32.6 \pm 15.6$ & $56.1 \pm 0.1$ \\
\hline $2 \mathrm{e}$ & & $\mathrm{H}$ & $26.0 \pm 2.1$ & $6.0 \pm 4.9$ & $44.9 \pm 4.7$ \\
\hline $2 f$ & & $\mathrm{H}$ & $26.6 \pm 1.2$ & $42.3 \pm 13.2$ & $50.6 \pm 4.2$ \\
\hline $2 \mathrm{~g}$ & & $\mathrm{OCH}_{3}$ & $33.6 \pm 11.9$ & $43.3 \pm 1.1$ & $39.6 \pm 8.1$ \\
\hline $2 \mathrm{~h}$ & & $\mathrm{OCH}_{3}$ & $82.2 \pm 4.8$ & $34.5 \pm 12.1$ & $58.7 \pm 3.3$ \\
\hline $2 \mathrm{i}$ & & $\mathrm{OCH}_{3}$ & $37.7 \pm 2.4$ & $18.1 \pm 16.9$ & $13.8 \pm 1.0$ \\
\hline Etoposide & - & - & $68.7 \pm 11$ & $54 \pm 10$ & inactive \\
\hline
\end{tabular}

Compounds $\mathbf{2 d}$ and $\mathbf{2} \mathbf{f}$ induced an increase of DNA subdiploid in MCF-7 cells, but not in HL60 (p53-null). It has been described that exposure of wild-type p53 cells to DNA-damaging agents increases p53 protein levels leading to $\mathrm{G} 1$ or $\mathrm{G} 2$ cell cycle blockage or apoptosis induction (Robinson, Shewach, 2001). The cross-talking between p53 function and cytotoxicity is a complex process and dependent upon the particular cytotoxic agent, cell line, and 
TABLE II - $\mathrm{IC}_{50}$ values and evaluation of pro-apoptotic potential of the compounds $\mathbf{2} \mathbf{d}, \mathbf{2} \mathbf{f}$ e $\mathbf{2} \mathbf{h}$

\begin{tabular}{lcccccc}
\hline Compounds & \multicolumn{2}{c}{$\mathbf{C I}_{\mathbf{5 0}}(\boldsymbol{\mu M})$} & \multicolumn{2}{c}{ \% hypodiploid DNA } \\
\cline { 2 - 7 } & HL60 & Jurkat & MCF-7 & Vero & HL60 & MCF-7 \\
\hline $\mathbf{2 d}$ & $>100$ & $>100$ & $54 \pm 11$ & $>100$ & ND* & $\mathbf{5 3 . 8} \pm \mathbf{4 . 2}$ \\
2f & $>100$ & $>100$ & $43 \pm 13$ & $>100$ & ND* & $\mathbf{4 5} \pm \mathbf{1 6}$ \\
2h & $43 \pm 3$ & $>100$ & $76 \pm 10$ & $>100$ & $\mathbf{9 0 . 9} \pm \mathbf{2}$ & $\mathbf{5 0 . 9} \pm \mathbf{1 2}$ \\
Etoposide & $16 \pm 4$ & $39 \pm 9$ & $>100$ & $>100$ & $\mathbf{8 6} \pm \mathbf{9}$ & $\mathbf{7 . 6} \pm \mathbf{3}$ \\
\hline
\end{tabular}

*ND $=$ not determined

cell death pathways used. Our results also corroborated the data by (Tudor et al., 2000), that demonstrated differences in susceptibility to drugs in HL60 and MCF-7 which has been attributed to qualitative changes in apoptotic protein expression, after exposure to agents with different mechanisms of action. Under our conditions, the positive control etoposide, used in the clinic, induced DNA fragmentation in HL60, but not in MCF-7. Shimizu and Pommier (1996) reported that topoisomerase inhibitors such as etoposide induce massive apoptosis in HL60 cells with the typical internucleosomal DNA fragmentation. Resistance to drugs, specifically to etoposide as observed in MCF-7, may arise as a result of alterations in target expression and activity, increased drug efflux, and alterations in DNA damage response mechanisms (Aktan et al., 2014). Therefore, further experiments should be conducted to elucidate the mechanism/s involved in the cytotoxic effect of the new thiosemicarbazones on these cell lines.

\section{CONCLUSION}

A series of thiosemicarbazones and their thiazole derivatives were synthesized in this work. All compounds were evaluated in vitro against three human cancer cell lines. Among the tested compounds, the thiazole heterocycles 2d, $\mathbf{2 f}$ and $\mathbf{2 h}$ exhibited moderate cytotoxicity activity against HL60 and/or MCF-7 cell lines ( $\mathrm{IC}_{50}$ range: 43-76 M) and low cytotoxicity against Vero cells (normal cells) $\left(\mathrm{IC}_{50}>100 \mu \mathrm{M}\right)$. The potential pro-apoptotic of the three compounds was investigated, demonstrating a difference in induction of DNA fragmentation in HL60 and MCF-7 cells. Among the active compounds, $\mathbf{2} \mathbf{h}$ displayed the best results in this preliminary study and can be considered a promising lead compound in the design of more potent analogues.

\section{ACKNOWLEDGMENT}

We are grateful to CNPq, FAPEMIG and INCT_if for financial support.

\section{REFERENCES}

ABDEL-MAKSOUD, M.S.; EL-GAMAL, M.I.; EL-DIN, M.M.G.; KWAK, S.S.; KIM, H.I.; OH, C.H. Broad-spectrum antiproliferative activity of a series of 6-(4-fluorophenyl)5-(2-substituted pyrimidin-4-yl)imidazo[2,1-b]thiazole derivatives. Med. Chem. Res., v.25, n.5, p.824-833, 2016.

BEHNISCH, R.; MIETZSCH, F.; SCHMIDT, H. Pyridine thiosemicarbazone. US Pat. 2.719.161, 27 set. 1955. 2p.

BHARTI, S.K.; NATH, G.; TILAK, R.; SINGH, S.K. Synthesis, anti-bacterial and anti-fungal activities of some novel Schiff bases containing 2,4-disubstituted thiazole ring. Eur. J. Med. Chem., v.45, n.2, p.651-660, 2010.

BILINSKI, S.; TYBURCZYK, W.; URBAN, T. Condensation of thiosemicarbazones of nicotinic and isonicotinic aldehydes with halo ketones. Ann. Univ. Mariae Curie-Sklodowska, Lublin-Polonia, v.15, p.123-128, 1961.

DIMMOCK, J.R.; McCOLL, J.M.; WONKO, S.L.; THAYER, R.S.; HANCOCK, D.S. Evaluation of the thiosemicarbazones of some aryl alkyl ketones and related compounds for anticonvulsivant activities. J. Med. Chem., v.26, n.5, p.529-534, 1991.

FESIK, S.W. Promoting apoptosis as a strategy for cancer drug discovery. Nat. Rev. Cancer, v.5, n.11, p.876-885, 2005.

FISCHER, U.; SCHULZE-OSTHOFF, K. New approaches and therapeutics targeting apoptosis in disease. Pharmacol. Rev., v.57, n.2, p.187-215, 2005.

FRIDMAN, J.R.; LOWE, S.W. Control of apoptosis by p53. Oncogene, v.22, p.9030-9040, 2003. 
GAIKWAD, N.D.; PATIL, S.V.; BOBADE, V.D. Synthesis and antimicrobial activity of novel thiazole substituted pyrazole derivatives. J. Het. Chem., v.50, n.3, p.519-527, 2013.

GRAMMATICAKIS, P.; SORBONNE, P. Absorption in the middle ultraviolet and the visible of 2-formyl- and 4-formylquinoline and their nitrogenous functional derivatives. Compt. Rend., v.248, p.3719-3721, 1959.

JU, J.F.; BANERJEE, D.; LENZ, H.J.; DANENBERG, K.D.; SCHMITTGEN, T.C.; SPEARS C.P.; SCHÖNTHAL, A.H.; MANNO, D.J.; HOCHHAUSER, D.; BERTINO, J.R.; DANENBERG, P.V. Restoration of wild-type p53 activity in p53-null HL-60 cells confers multidrug sensitivity. Clin. Cancer Res., v.4, n.5, p.1315-1322, 1998.

KÜSTER, T.; LENSE, N.; BARNA, F.; HEMPHILL, A.; KINDERMANN, M.K.; HEINICKE, J.W.; VOCK, C.A. A new promising application for highly cytotoxic metal compounds: $\eta 6$-areneruthenium(II) phosphite complexes for the treatment of alveolar echinococcosis. J. Med. Chem., v.55, n.9, p.4178-4188, 2012.

LAGES, E.B.; FREITAS, M.B.; GONÇALVES, I.M.B.; ALVES, R.J.; VIANNA-SOARES, C.D.; FERREIRA, L.A.; OLIVEIRA, M.C.; OLIVEIRA, R.B. Evaluation of antitumor activity and development of solid lipid nanoparticles of metronidazole analogue. J. Biomed. Nanotechnol., v.9, n.11, p.1939-1944, 2013.

LAVRADO, J.; RESZKA, A.P.; MOREIRA, R.; NEIDLE, S.; PAULO, A. C-11 diamino cryptolepine derivatives NSC748392, NSC748393, and NSC748394: anticancer profile and G-quadruplex stabilization. Bioorg. Med. Chem. Lett., v.20, n.23, p.7042-7045, 2010.

MACCIONI, E.; CARDIA, M.C.; DISTINTO, S.; BONSIGNORE L.; De LOGU, A. An investigation of the biological effect of structural modifications of isothiosemicarbazones and their cyclic analogues. Farmaco, v.58, n.9, p.951-959, 2003.

MORIGI, R.; LOCATELLI, A.; LEONI, A.; RAMBALDI, M. Recent patents on thiazole derivatives endowed with antitumor activity. Recent Pat. Anti-Canc., v.10, n.3, p.280$297,2015$.

MOSMANN, T. Rapid colorimetric assay for cellular growth and survival: application to proliferation and cytotoxicity assays. J. Immunol. Methods, v.65, n.1-2, p.55-63, 1983.
NICOLETTI, I.; MIGLIORATI, G.; PAGLIACCI, M.C.; GRIGNANI, F; RICCARDI, C. A rapid and simple method for measuring thymocyte apoptosis by propidium iodide staining and flow cytometry. J. Immunol. Methods, v.139, n.2, p.271-279, 1991.

OLIVEIRA, R.B.; SOUZA-FAGUNDES, E.M.; SIQUEIRA, H.A.; LEITE, R.S.; DONNICI, C.L.; ZANI, C.L. Synthesis and evaluation of cytotoxic activity of arylfurans. Eur. J. Med. Chem., v.41, n.6, p.756-760, 2006.

OLIVEIRA, R.B.; SOUZA-FAGUNDES, E.M.; SOARES, R.P.; ANDRADE, A.A.; KRETTLI, A.U.; ZANI, C.L. Synthesis and antimalarial activity of semicarbazone and thiosemicarbazone derivatives. Eur. J. Med. Chem., v.43, n.9, p.1983-1988, 2008a.

OLIVEIRA, R.B.; ZANI, C.L.; FERREIRA, R.S.; LEITE, R.S.; ALVES, T.M.A.; SILVA, T.H.A.; ROMANHA, A.J. Síntese, avaliação biológia e modelagem molecular de arilfuranos como inibidores da enzima tripanotiona redutase. Quim. Nova, v.31, n.2, p.261-267, 2008 b.

RAJAK, H.; AGARAWAL, A.; PARMAR, P.; THAKUR B.S.; VEERASAMY, R.; SHARMA, P.C.; KHARYA, M.D. 2,5-Disubstituted-1,3,4-oxadiazoles/thiadiazole as surface recognition moiety: design and synthesis of novel hydroxamic acid based histone deacetylase inhibitors. Bioorg. Med. Chem. Lett., v.21, n.19, p.5735-5738, 2011.

ROBINSON, B.W.; SHEWACH, D.S. Radiosensitization by gemcitabine in p53 wild-type and mutant MCF-7 breast carcinoma cell lines. Clin. Cancer Res., v.7, n.8, p.25812589, 2001.

SHIH, M.H.; SU, Y.S.; WU, C.L. Syntheses of aromatic substituted hydrazino-thiazole derivatives to clarify structural characterization and antioxidant activity between 3-arylsydnonyl and aryl substituted hydrazino-thiazoles. Chem. Pharm. Bull., v.55, n.8, p.1126-1135, 2007.

SHIMIZU, T.; POMMIER, Y. DNA fragmentation induced by protease activation in p53-null human leukemia HL60 cells undergoing apoptosis following treatment with the topoisomerase I inhibitor camptothecin: cell-free system studies. Exp. Cell Res., v.226, n.2, p.292-301, 1996.

SIDDIQUI, N.; ARSHAD, M.F.; AHSAN, W.; ALAM , M.S. Thiazoles: a valuable insight into the recent advances and biological activities. Int. J. Pharm. Sci. Drug Res., v. 1, n. 3, p. 136-143, 2009. 
SOARES, G.A.; OLIVEIRA, R.B.; ANDRADE, S.F.; ALVES, R.J.; ZANI, C.L.; SOUZA-FAGUNDES, E.M. Synthesis and in vitro cytotoxic activity of compounds with proapoptotic potential. Molecules, v.15, n.1, p.12-26, 2010.

SOUZA, M.A.; JOHANN S.; LIMA, L.A.R.S.; CAMPOS, F.F.; MENDES, I.C.; BERALDO, H.; SOUZA-FAGUNDES, E.M.; CISALPINO, P.S.; ROSA, C.A.; ALVES, T.M.; SÁ, N.P.; ZANI, C.L. The antimicrobial activity of lapachol and its thiosemicarbazone and semicarbazone derivatives. Mem. Inst. Oswaldo Cruz, v.108, n.3, p.342-351, 2013.

SOUZA, M.V.N. Synthesis and biological activity of natural thiazoles: an important class of heterocyclic compounds. J. Sulfur. Chem., v.26, n.4-5, p.429-449, 2005.

TENÓRIO, R.P.; CARVALHO, C.S.; PESSANHA, C.S. Synthesis of thiosemicarbazone and 4-thiazolidinone derivatives and their in vitro anti-Toxoplasma gondi activity. Bioorg. Med. Chem. Lett., v.15, n.10, p.2575-2578, 2005.

TUDOR, G.; AQUILERA, A.; HALVERSON, D.O.; LAING, N.D.; SAUSVILLE, E.A. Susceptibility to drug-induced apoptosis correlates with differential modulation of Bad, Bcl-2 and Bcl-xL protein levels. Cell Death and Differ., v.7, n.6, p.574-586, 2000.
TURAN-ZITOUNI, G.; ALTINTOP, M.D.; OZDEMIR, A.; KAPLANCIKLI, Z.A.; CIFTCI, G.A.; TEMEL, H.E. Synthesis and evaluation of bis-thiazole derivatives as new anticancer agents. Eur. J. Med. Chem., v.107, p.288-294, 2016.

ULUKAYA, E.; COLAKOGULlARI, M.; WOOD, E.J. Interference by anti-cancer chemotherapeutic agents in the MTT-tumor chemosensitivity assay. Chemotherapy, v.50, n. 1, p.43-50, 2004.

WEBER, B.; SERAFIN, A.; MICHIE, J.; Van RENSBURG, C.; SWARTS, J.C.; BOHM, L. Cytotoxicity and cell death pathways invoked by two new rhodium-ferrocene complexes in benign and malignant prostatic cell lines. Anticancer Res., v.24, n.2B, p.763-770, 2004.

ZHAO, M.Y.; YIN, Y.; YU, X.W.; SANGANI, C.B.; WANG, S.F.; LU, A.M.; YANG, L.F.; LV, P.C.; JIANG, M.G.; ZHU, H.L. Synthesis, biological evaluation and 3D-QSAR study of novel 4,5-dihydro- $1 H$-pyrazole thiazole derivatives as BRAF ${ }^{\mathrm{V} 600 \mathrm{E}}$ inhibitors. Bioorg. Med. Chem., v.23, n.1, p.4654, 2015.

Received for publication on $25^{\text {th }}$ June 2015 Accepted for publication on $07^{\text {th }}$ May 2016 
